\title{
Influence of Concentration of Soda Ash, Temperature, and Immersion Period on the Control of Postharvest Green Mold of Oranges
}

J. L. Smilanick, Horticultural Crops Research Laboratory, USDA-ARS, 2021 South Peach Avenue, Fresno, CA 93727; B. E. Mackey, Biometrics Unit, Western Regional Research Center, USDA-ARS, 800 Buchanan Street, Albany, CA 94710; R. Reese, Applications Supervisor, Research and Technical Services, Fresh Fruit Sciences, Sunkist Growers, 22 West Lindmore Street, Lindsay, CA 93247; J. Usall, Area de Postcollita, CeRTA, Centre UdLIRTA, Ave. Rovira Roure, 177, 25198 Lleida, Catalonia, Spain; and D. A. Margosan, USDA-ARS, 2021 South Peach Avenue, Fresno, CA 73727

\section{ABSTRACT}

Smilanick, J. L., Mackey, B. E., Reese, R., Usall, J., and Margosan, D. A. 1997. Influence of concentration of soda ash, temperature, and immersion period on the control of postharvest green mold of oranges. Plant Dis. 81:379-382.

Oranges were inoculated with spores of Penicillium digitatum, the citrus green mold pathogen, and immersed $24 \mathrm{~h}$ later in heated soda ash $\left(\mathrm{Na}_{2} \mathrm{CO}_{3}\right.$, sodium carbonate) solutions to control postharvest citrus green mold. Oranges were immersed for 1 or $2 \mathrm{~min}$ in solutions containing 0 , 2,4 , or $6 \%$ (wt/vol) soda ash heated to $35.0,40.6,43.3$, or $46.1^{\circ} \mathrm{C}$. After 3 weeks of storage at $10^{\circ} \mathrm{C}$, the number of decayed oranges was determined. Soda ash significantly controlled green mold in every test. The most effective control of green mold was obtained at 40.6 or $43.3^{\circ} \mathrm{C}$ with 4 or $6 \%$ soda ash. The concentration of soda ash greatly influenced efficacy, whereas the influences of temperature or immersion period on soda ash efficacy were small. Solutions of 4 and $6 \%$ soda ash were similar in efficacy and provided superior control of green mold compared with $2 \%$ soda ash. The control of green mold by soda ash solutions heated to 40.6 or $43.3^{\circ} \mathrm{C}$ was slightly superior to control by solutions heated to 35.0 or $46.1^{\circ} \mathrm{C}$. The control of green mold by 1-min immersion of inoculated oranges in heated soda ash solutions was inferior to immersion for $2 \mathrm{~min}$, but the magnitude of the difference, particularly with $6 \%$ soda ash, was small. A second-order response surface model without interactions was developed that closely described the influence of soda ash concentration, temperature, and immersion period on efficacy. The efficacy of soda ash under commercial conditions was better than that predicted by the model, probably because under commercial conditions the fruit were rinsed less thoroughly with water after treatment than in laboratory tests. The primary finding of this work was that soda ash controlled 24-h-old green mold infections at commercially useful levels using shorter immersion periods and lower temperatures than those recommended by other workers for the use of soda ash on lemons. The oranges were not visibly injured in any test.
\end{abstract}

Green mold of citrus, caused by Penicillium digitatum (Pers.:Fr.) Sacc., is one of the most economically important postharvest diseases of citrus worldwide (6). Powell (18) established that the primary infection sites of $P$. digitatum are wounds inflicted on fruit during harvest and subsequent handling. Eradication of these incipient infections on the fruit, often as old as $24 \mathrm{~h}$ when fungicidal treatments are applied, is required to achieve acceptable levels of control $(5,6)$. Currently, green mold on oranges is controlled in California primarily by applications of the fungicides ortho-phenyl phenate, imazalil, and thia-

Corresponding author: J. L. Smilanick

E-mail: jsmilanick@aol.com

Accepted for publication 7 January 1997.

Publication no. D-1997-0128-06R

This article is in the public domain and not copyrightable. It may be freely reprinted with customary crediting of the source. The American Phytopathological Society, 1997. bendazole. New methods are needed, because pathogen resistance to these chemicals has developed $(3,7)$ and regulatory issues and public concerns about health risks of ingesting fungicide residues threaten the continued use of fungicides in the future (16).

Soda ash $\left(\mathrm{Na}_{2} \mathrm{CO}_{3}\right.$, sodium carbonate) has been used to improve cleaning and to control postharvest decay of citrus fruit in California for more than 70 years (6). Today, it is often used on lemons before storage and occasionally on oranges. Recently, we compared the efficacy of soda ash treatments to the fungicide imazalil on lemons to control green mold and showed that soda ash treatments were equal to or superior to imazalil; soda ash treatments reduced the incidence of green mold by more than $90 \%$, even when applied to lemons inoculated as long as $48 \mathrm{~h}$ prior to the application of the soda ash treatment (20). However, many aspects of soda ash use have not been examined, and few publications exist to give clear guidance on how it should be used, particularly on or- anges (6). Klotz (13) recommended immersion of citrus fruit for 3 to $4 \mathrm{~min}$ in 1.5 to $3.0 \%$ soda ash at 37.7 to $43.3^{\circ} \mathrm{C}$ to control green mold but did not present any information to support this recommendation. Our objective was to determine the magnitude of the influences of the length of immersion in soda ash solutions, soda ash temperature, and soda ash concentration on the control of postharvest green mold on oranges.

\section{MATERIALS AND METHODS}

Fruit. Navel and Valencia oranges used in experiments were grown in California and selected by hand from field bins after harvest before any commercial postharvest treatments were applied. Blemish-free, orange-colored fruits 70 to $75 \mathrm{~mm}$ in diameter were selected and stored at $10^{\circ} \mathrm{C}$ no longer than 2 days after harvest. Before each experiment, the oranges were washed with water on commercial processing equipment and randomized. The temperature of the fruit at the time of treatment was 18 to $22^{\circ} \mathrm{C}$.

Inoculum. Petri dishes of potato-dextrose agar were inoculated with $P$. digitatum isolate M6R (obtained from J. W. Eckert, University of California, Riverside) and incubated at $20^{\circ} \mathrm{C}$ for 1 to 2 weeks. Spores were rubbed from the agar surface with a glass rod after a small volume of sterile $0.05 \%$ Triton X-100 was added. The spore suspension was passed through two layers of cheesecloth and diluted with sterile water to an absorbance of 0.1 at 420 $\mathrm{nm}$. This density, approximately equivalent to $1 \times 10^{6}$ spores per $\mathrm{ml}$, is recommended for evaluation of postharvest treatments to control green mold (5). Fruits were inoculated by puncturing each fruit once with a stainless steel probe with a tip $2 \mathrm{~mm}$ long and $1 \mathrm{~mm}$ wide that had been dipped into the inoculum solution just before use. The shallow wounds penetrated the albedo tissue but not the juice sacs and simulated natural inoculation (5).

Green mold incidence. The number of infected fruit was counted after 3 weeks of storage at $10^{\circ} \mathrm{C}$. Little change in green mold incidence occurred if storage was longer than 3 weeks. This temperature was selected because green mold develops 
rapidly at $10^{\circ} \mathrm{C}$ and because it represents a mean value among storage and transit temperatures encountered commercially.

Fruit quality. Heat injury to citrus fruit is usually evident as injury to the rind and is termed scalding $(14,21)$. Therefore, in every test, the presence of rind injuries was quantified by a 0 to 3 rating. Injury classes were: $0=$ none, no injury or not different from the control, $1=$ minor, slight to $10 \%$ of rind surface injured; $2=$ moderate, 11 to $30 \%$ of rind surface injured; and $3=$ severe, more than $30 \%$ of rind surface injured.

Soda ash treatments. Glass tanks holding 22 liters of water or soda ash were suspended in a 300-liter heated water tank.
The fruits were treated for one 1 or $2 \mathrm{~min}$ in soda ash solutions heated to $35.0,40.6$, 43.3 , or $46.1^{\circ} \mathrm{C}$. Soda ash (Sigma Chemical Co., $\mathrm{pH} 11.3$ to 11.5 ) concentrations were $0,2,4$, or $6 \%$. These values encompass temperatures and soda ash concentrations frequently used in commercial practice and that evaluated encompass those recommended for soda ash on citrus fruit (13). Baskets containing 25 inoculated fruits were suspended in the soda ash solutions; the fruits were rinsed with fresh water for $5 \mathrm{~s}$ and stored for 3 weeks at $10^{\circ} \mathrm{C}$, at which time moldy fruits were counted and any injury to the fruit was noted. Soda ash concentration in the solutions was determined periodically with a

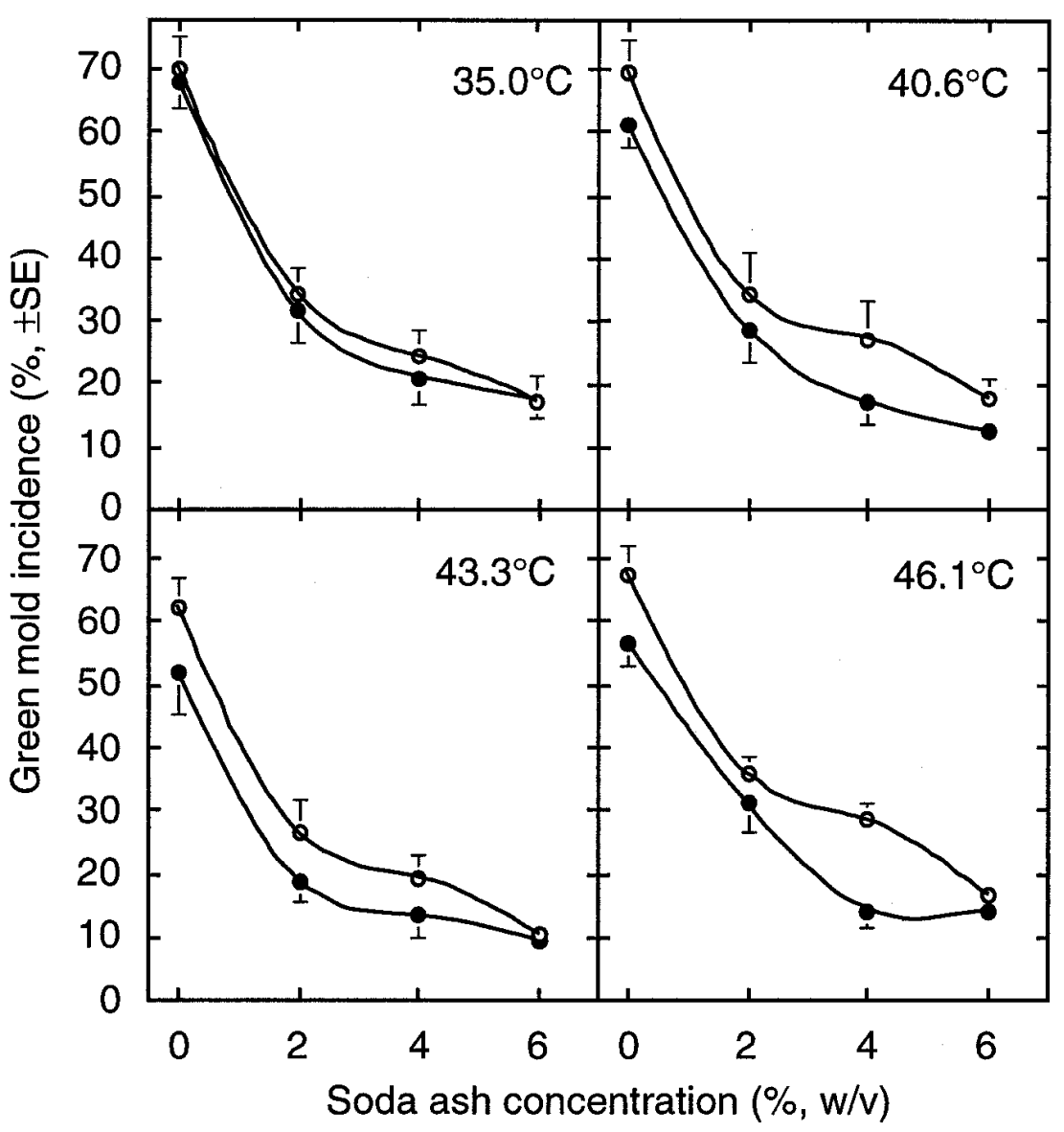

Fig. 1. Influence of 1 (o) or $2 \min (\bullet)$ of immersion of oranges in heated soda ash solutions on the incidence of citrus green mold caused by Penicillium digitatum after storage for 3 weeks.

Table 1. Analysis of variance of the incidence of green mold caused by Penicillium digitatum among oranges immersed in soda ash and stored 3 weeks at $10^{\circ} \mathrm{C}$

\begin{tabular}{lcccc}
\hline Source $^{\mathbf{a}}$ & df & Mean square & $\boldsymbol{F}$ value & $\boldsymbol{P}$ \\
\hline Experiment (E) & 2 & 0.3251 & 42.57 & 0.0001 \\
Temperature (T) & 3 & 0.0513 & 6.72 & 0.0005 \\
Soda ash (SA) & 3 & 1.3753 & 180.04 & 0.0001 \\
Immersion period (IP) & 1 & 0.1106 & 14.49 & 0.0003 \\
$\mathrm{~T} \times \mathrm{SA}$ & 9 & 0.0024 & 0.31 & 0.9693 \\
$\mathrm{~T} \times$ IP & 3 & 0.0055 & 0.72 & 0.5458 \\
$\mathrm{SA} \times$ IP & 3 & 0.0073 & 0.95 & 0.4206 \\
$\mathrm{~T} \times \mathrm{SA} \times$ IP & 9 & 0.0013 & 0.17 & 0.9961 \\
Error & 62 & & & 0.0076 \\
\hline
\end{tabular}

a Analysis was applied to the arcsine of the square root of the proportion of decayed fruit. salt refractometer (Model 300011, Sper Scientific Limited, Scottsdale, AZ) and did not change during the experiments. Each treatment was applied to four replicates of 25 fruits each within each experiment. The entire experiment was repeated three times, twice with Valencia oranges and once with navel oranges.

Statistical analysis. A three-way analysis of variance was applied to the arcsine of the square root of the proportion of decayed fruit. A second-order response surface model was fitted using SAS PROC GLM (SAS Institute, Cary, NC) to predict the incidence of decay and $95 \%$ confidence intervals $(\mathrm{CI})$.

Confirmatory test under commercial conditions. Freshly harvested Valencia oranges were inoculated once each about $24( \pm 2)$ h before treatment with Penicillium digitatum isolate M6R. Each treatment was applied to four replicates composed of 60 oranges each. Each replicate was placed on the processing line just before a high-pressure water washer that contained 10 to $50 \mu \mathrm{g}$ of sodium hypochlorite per $\mathrm{ml}$. The resident time in the pressure washer, operating at 1,500 Newtons pressure, was about $12 \mathrm{~s}$. Following the pressure washer, the fruit passed for 15 to $20 \mathrm{~s}$ through a high-velocity air-drier operating at $32.2^{\circ} \mathrm{C}$ to a moving-belt sorting table, where decayed or damaged fruits were removed. They then passed into a 2,400-liter-capacity tank containing water heated to $37.8^{\circ} \mathrm{C}$ or a solution of $3 \%$ (wt/vol) soda ash heated to $37.8^{\circ} \mathrm{C}$. The resident time of the fruit in the tank was 60 s. After treatment in the tank, the fruits were rinsed about $1 \mathrm{~s}$ with fresh water, dried for 15 to $20 \mathrm{~s}$ by passage through a high-velocity air-drier operating at $32.2^{\circ} \mathrm{C}$, a high resin content finishing wax (Sealbrite 504, EcoScience Corp., Orlando, FL) was applied, and the fruits were dried again for 15 to $20 \mathrm{~s}$ through a high-velocity air-drier operating at $32.2^{\circ} \mathrm{C}$. The fruits were packaged in commercial fiberboard cartons, and the incidence of green mold was recorded after 3 weeks storage at $10^{\circ} \mathrm{C}$.

\section{RESULTS}

Soda ash reduced green mold from about $70 \%$ to 10 or $20 \%$ in every test (Fig. 1). Soda ash concentration, temperature, and immersion period all significantly influenced the incidence of green mold (Table $1)$. The concentration of soda ash greatly influenced efficacy, whereas differences among temperatures or between immersion periods were small. Concentrations of 4 and $6 \%$ soda ash were superior to $2 \%$. Results at 35.0 or $46.1^{\circ} \mathrm{C}$ were similar and only slightly inferior in efficacy to those at 40.6 or $43.3^{\circ} \mathrm{C}$. Immersion in soda ash for $1 \mathrm{~min}$ was inferior to immersion for $2 \mathrm{~min}$, but the magnitude of the difference was very small, particularly with $6 \%$ soda ash. The most effective temperature and soda 
ash combinations were 40.6 or $43.3^{\circ} \mathrm{C}$ with 4 or $6 \%$ soda ash. No rind injury occurred in any test.

A three-way analysis was applied to the arcsine square root of the proportion of decayed fruit, and interactions among temperature, soda ash concentration, and immersion period were not significant $(P>$ 0.42; Table 1). A second-order response surface model without interaction was developed (Table 2) to predict the incidence of decay. The lack of fit test for the model was not significant $(P=0.44)$. The predicted arcsine square root of the proportion of decay $=0.9936-0.002390\left({ }^{\circ} \mathrm{C}-\right.$ 106.25) - 0.1904(\% soda ash) -0.06790 (immersion period) $+0.001391\left({ }^{\circ} \mathrm{C}-106.25\right)^{2}$ $+0.01727(\% \text { soda ash })^{2}$. The percentage of decay $=100[\sin$ (predicted arcsine square root of the proportion of decay) $]^{2}$. The predicted and actual values were similar (Table 3).

The model developed from laboratory tests predicted a slightly lower incidence of decay among water-treated oranges and a slightly higher incidence of decay among soda ash-treated oranges than was actually obtained under commercial conditions. The decay $( \pm 95 \% \mathrm{CI})$ predicted to occur by the model after 1 min immersion in water alone at $37.8^{\circ} \mathrm{C}$ or a solution of $3 \%$ soda ash at $37.8^{\circ} \mathrm{C}$ was $66.2 \%(61.2,70.7)$ or $26.0 \%(22.7,29.6)$, respectively. The decay $( \pm \mathrm{SD})$ that occurred under commercial conditions after $1 \mathrm{~min}$ immersion in water alone at $37.8^{\circ} \mathrm{C}$ or a solution of $3 \%$ soda ash at $37.8^{\circ} \mathrm{C}$ was $85.2 \%( \pm 6)$ and $10.0 \%$ $( \pm 3.2)$, respectively. No rind injury occurred in any test.

\section{DISCUSSION}

Although soda ash did not injure oranges in our tests, there is some risk of injury to the fruit, and this issue deserves special attention because this risk is the primary reservation packinghouse managers have about the adoption of this practice. Our work shows heating soda ash to temperatures previously associated with the risk of injury to fruit is not needed to obtain good control of green mold. Many workers immersed citrus fruit in water at higher temperatures and for longer periods than in our work without injury to the fruit $(2,12,19,21)$. To control green mold, Houck (12) recommended 5 to $10 \mathrm{~min}$ immersion of lemons in water at $51.7^{\circ} \mathrm{C}$ or $1 \mathrm{~min}$ at $54.4^{\circ} \mathrm{C}$. This treatment was tolerated by yellow, winter-harvested lemons, the most sensitive fruit he tested, and was readily tolerated by green, summer-harvested lemons, the most resistant fruit to heat injury. Klotz and DeWolfe $(14,15)$ cautioned that although lemons could routinely tolerate immersion in water for 4 min or longer at 46.1 to $48.9^{\circ} \mathrm{C}$ without injury, release of rind oils leading to oleocellosis could occur if lemons were cold and turgid at the time of immersion. They (15) and others $(8,12,17)$ recommended fruit conditioning, which consists of delaying immersion for 1 to 4 days after harvest to allow the rind to lose turgor. Without conditioning, turgid, freshly picked, winter-harvested lemons could be injured by temperatures as low as $37.8^{\circ} \mathrm{C}(8)$. As an additional precaution, Klotz and DeWolfe (15) suggested using a soap in a posttreatment rinse to entrap released oils and terpenoids to further reduce chances of rind injury. Early-maturing citrus varieties are reported to be more easily injured by physical and chemical treatments than are later maturing fruit (12), and their susceptibility to soda ash injury should be exam- ined before they are treated with soda ash on a commercial scale. In a preliminary test, we immersed five early-season navel orange varieties (Newhall, Thompson Improved, Fisher, Atwood, and Bonanza) 1 to 2 days after harvest in $3 \%$ soda ash for 1 min at 18 to $60^{\circ} \mathrm{C}$, then rinsed, dried, and waxed the fruit. After 3 weeks of storage at $10^{\circ} \mathrm{C}$, rind injury only occurred after treatment at temperatures above $50^{\circ} \mathrm{C}(\mathrm{J}$. L. Smilanick, unpublished).

Some aspects of soda ash use remain incompletely examined. In our work, all fruit were artificially inoculated, and some investigators warn that confirmatory studies

Table 2. Analysis of variance of elements of a second-order surface model to predict the efficacy of soda ash treatments on oranges to control green mold caused by Penicillium digitatum ${ }^{\mathrm{a}}$

\begin{tabular}{lcccc}
\hline Parameter & Estimate & $\begin{array}{c}\text { Standard error } \\
\text { of estimate }\end{array}$ & $\boldsymbol{t}$ value & $\boldsymbol{P}$ \\
\hline Intercept & 0.9936 & 0.0339 & 29.27 & 0.0001 \\
Temperature (T) & -0.0024 & 0.0025 & -0.96 & 0.3373 \\
Soda ash (SA) & -0.1904 & 0.0140 & -13.56 & 0.0001 \\
Immersion period & -0.0679 & 0.0179 & -3.79 & 0.0003 \\
T $\times$ T & 0.0014 & 0.0007 & 2.12 & 0.0367 \\
SA $\times$ SA & 0.0173 & 0.0022 & 7.70 & 0.0001 \\
\hline
\end{tabular}

a The arcsine of the square root of the proportion of decayed fruit $=0.9936-0.002390\left({ }^{\circ} \mathrm{C}-106.25\right)-$ 0.1904 (\% soda ash) -0.06790 (immersion period) $+0.001391\left({ }^{\circ} \mathrm{C}-106.25\right)^{2}+0.01727(\%$ soda ash $)^{2}$. The percentage of decay $=100\left[\sin (\text { predicted arcsine square root of the proportion of decay) }]^{2}\right.$.

Table 3. The predicted and actual incidence of green mold caused by Penicillium digitatum decay among oranges treated with soda ash

\begin{tabular}{|c|c|c|c|c|c|c|}
\hline \multirow[b]{2}{*}{$\operatorname{Temp}\left({ }^{\circ} \mathbf{C}\right)$} & \multirow{2}{*}{$\begin{array}{c}\text { Soda ash } \\
(\%)\end{array}$} & \multirow{2}{*}{$\begin{array}{l}\text { Immersion } \\
\text { time (min) }\end{array}$} & \multicolumn{4}{|c|}{ Green mold incidence (\%) } \\
\hline & & & Predicted & $( \pm 95 \% \mathrm{CI})^{\mathrm{a}}$ & Actual & $( \pm \mathrm{SE})^{\mathrm{b}}$ \\
\hline \multirow[t]{8}{*}{35.0} & 0 & 1 & 70.4 & $(65.7,74.8)$ & 69.9 & $( \pm 5.3)$ \\
\hline & 0 & 2 & 64.0 & $(59.2,68.7)$ & 68.1 & $( \pm 4.6)$ \\
\hline & 2 & 1 & 39.9 & $(35.6,44.2)$ & 34.3 & $( \pm 3.9)$ \\
\hline & 2 & 2 & 33.3 & $(29.2,37.5)$ & 31.4 & $( \pm 5.2)$ \\
\hline & 4 & 1 & 23.8 & $(20.2,27.7)$ & 24.3 & $( \pm 4.4)$ \\
\hline & 4 & 2 & 18.3 & $(15.0,21.8)$ & 20.9 & $( \pm 4.4)$ \\
\hline & 6 & 1 & 20.9 & $(17.0,25.0)$ & 17.3 & $( \pm 4.1)$ \\
\hline & 6 & 2 & 15.6 & $(12.2,19.4)$ & 17.3 & $( \pm 3.0)$ \\
\hline \multirow[t]{8}{*}{40.6} & 0 & 1 & 64.1 & $(59.7,68.4)$ & 69.4 & $( \pm 5.6)$ \\
\hline & 0 & 2 & 57.5 & $(52.9,61.9)$ & 61.3 & $( \pm 3.6)$ \\
\hline & 2 & 1 & 33.4 & $(29.8,37.2)$ & 34.3 & $( \pm 7.0)$ \\
\hline & 2 & 2 & 27.2 & $(23.8,30.8)$ & 28.7 & $( \pm 5.4)$ \\
\hline & 4 & 1 & 18.4 & $(15.4,21.5)$ & 27.3 & $( \pm 5.9)$ \\
\hline & 4 & 2 & 13.4 & $(10.9,16.2)$ & 17.0 & $( \pm 3.6)$ \\
\hline & 6 & 1 & 15.7 & $(12.5,19.1)$ & 17.5 & $( \pm 3.6)$ \\
\hline & 6 & 2 & 11.1 & $(8.4,14.1)$ & 12.4 & $( \pm 2.0)$ \\
\hline \multirow[t]{8}{*}{43.3} & 0 & 1 & 64.0 & $(59.9,67.9)$ & 62.4 & $( \pm 4.8)$ \\
\hline & 0 & 2 & 57.3 & $(53.2,61.4)$ & 51.7 & $( \pm 6.5)$ \\
\hline & 2 & 1 & 33.3 & $(30.0,36.6)$ & 26.5 & $( \pm 5.2)$ \\
\hline & 2 & 2 & 27.1 & $(24.0,30.2)$ & 18.9 & $( \pm 3.4)$ \\
\hline & 4 & 1 & 18.3 & $(15.6,21.0)$ & 19.5 & $( \pm 3.5)$ \\
\hline & 4 & 2 & 13.3 & $(11.0,15.8)$ & 13.4 & $( \pm 3.5)$ \\
\hline & 6 & 1 & 15.6 & $(12.7,18.8)$ & 10.7 & $( \pm 1.8)$ \\
\hline & 6 & 2 & 11.0 & $(8.5,13.8)$ & 9.5 & $( \pm 1.4)$ \\
\hline \multirow[t]{8}{*}{46.1} & 0 & 1 & 65.9 & $(61.2,70.4)$ & 67.6 & $( \pm 4.7)$ \\
\hline & 0 & 2 & 59.3 & $(54.5,64.1)$ & 56.6 & $( \pm 3.5)$ \\
\hline & 2 & 1 & 35.2 & $(31.1,39.4)$ & 35.7 & $( \pm 2.8)$ \\
\hline & 2 & 2 & 28.9 & $(25.1,32.9)$ & 31.0 & $( \pm 4.3)$ \\
\hline & 4 & 1 & 19.8 & $(16.5,23.4)$ & 28.5 & $( \pm 2.7)$ \\
\hline & 4 & 2 & 14.7 & $(11.8,17.9)$ & 14.3 & $( \pm 2.9)$ \\
\hline & 6 & 1 & 17.1 & $(13.6,20.9)$ & 16.7 & $( \pm 1.8)$ \\
\hline & 6 & 2 & 12.3 & $(9.3,15.7)$ & 14.3 & $( \pm 1.8)$ \\
\hline
\end{tabular}

a The model used to predict the incidence of green mold and $95 \%$ confidence intervals $(\mathrm{CI})$ are from Table 2.

${ }^{\mathrm{b}} \mathrm{SE}=$ standard error; each value is the mean of three experiments with four replicates of 25 oranges each. 
with naturally inoculated fruit should be conducted to confirm conclusions obtained with artificially inoculated fruit $(1,4,10,14)$. For example, Barger (1) stated that lower concentrations of bicarbonate in water solutions were needed to control green mold of naturally inoculated oranges than of those artificially inoculated. The influence of temperatures lower than those we tested on decay control efficacy has not been systematically evaluated. In this work, differences in efficacy on the control of green mold of oranges within the narrow range of temperatures we examined were small. Similarly, Houck (11) reported the efficacy of $3 \%$ soda ash on the control of green mold of lemons was enhanced by heating the ash from 26 to $45^{\circ} \mathrm{C}$, although the magnitude of the benefit was small unless the immersion period was extended from 2 to $4 \mathrm{~min}$. On most processing lines, an immersion period of 1 min requires a tank approximately $10 \mathrm{~m}$ in length, and longer immersion tanks require proportionately more space and materials to construct. Tanks used by the lemon industry in California have temperature control, and even if heat did not substantially influence the efficacy of soda ash treatments, it is of sufficient benefit for other purposes that its use would remain if the use of soda ash on oranges became popular. Benefits of heat include: (i) heat accelerates the solubilization of soda ash added to replenish that carried out by treated fruit; (ii) heated solutions clean fruit better than cool solutions; (iii) fruit warmed during immersion treatments are thought to dry faster and accept wax coating more uniformly than cool or damp fruit; (iv) postharvest brown rot, caused by Phytophthora spp., can be controlled by hot water $\left(46.1\right.$ to $\left.48.9^{\circ} \mathrm{C}\right)$, although now brown rot control is primarily obtained by preharvest fungicides and cultural practices $(8,9,13)$; (v) the efficacy of both sodium ortho-phenyl phenate and borax-boric acid mixtures, the former in common use and the latter rarely used because of residue and disposal issues, is enhanced by heating when these are applied in tanks $(6,23)$; (vi) heat applied by hot water or moist air enhances resistance of fruit to subsequent chilling injury (Immersion in water at $50.0^{\circ} \mathrm{C}$ for $2 \mathrm{~min}$ did not injure and reduced subsequent susceptibility to chilling injury during storage of grapefruit [19,22], Valencia oranges [22], and Washington navel oranges [22]); and (vii) to control undesirable microbes and pathogens, solutions in tanks are often heat-pasteurized when fruit are not present.
The efficacy of soda ash under commercial conditions was better than that predicted by the model developed from laboratory results, probably because under commercial conditions the fruit were rinsed less thoroughly with water after treatment than in laboratory tests. In the laboratory tests, each fruit was uniformly rinsed for $5 \mathrm{~s}$ after treatment, whereas on the commercial processing line, rinsing was about $1 \mathrm{~s}$ and irregular. The volume of water applied to each fruit in both commercial and laboratory tests was about $8 \mathrm{ml}$ per orange. Winston (23) showed that adjusting the amount of water used to rinse oranges after they had been immersed in borax solutions was important to obtain reliable efficacy with this treatment. Excessive rinsing greatly reduced the efficacy of borax solutions. It is probable that, as with borax, the amount of soda ash remaining on the fruit influences the level of control obtained.

The primary findings of this work are that soda ash provides control of green mold of oranges without the need to heat the solutions to temperatures that increase the risk of injury to fruit, and even treatments as brief as 1 min worked effectively. Soda ash is an excellent tool to control postharvest decay of citrus; it is inexpensive, readily available, and its use is not encumbered by regulatory control or safety issues. It is already commonly used in lemon packinghouses, and this work indicates it could prove a useful treatment on oranges as well.

\section{ACKNOWLEDGMENTS}

We gratefully acknowledge useful ideas and suggestions of J. W. Eckert, P. Johnson, R. Elliott, and P. Lewis; the donations of labor and facilities from I. F. Michael, M. F. Mansour, and C. F. Weist of Advanced Packinghouse Systems, and D. Flores of Diversified Agricultural Consultants; and we thank the California Citrus Research Board for financial support.

\section{LITERATURE CITED}

1. Barger, W. R. 1928. Sodium bicarbonate as a citrus fruit disinfectant. Calif. Citrogr. 13:164-174.

2. Barkai-Golan, R., Kahan, R. S., and Padova, R. 1969. Synergistic effects of gamma radiation and heat on the development of Penicillium digitatum in vitro and in stored citrus fruits. Phytopathology 59:922-924.

3. Bus, V. G., Bongers, A. J., and Risse, L. A. 1991. Occurrence of Penicillium digitatum and $P$. italicum resistant to benomyl, thiabendazole, and imazalil on citrus fruit from different geographic origins. Plant Dis. 75:10981100.

4. Cohen, E. 1991. The use of temperature for postharvest decay control in citrus fruit. Pages 256-263 in: Biol. Control Postharvest Dis.
Fruits Vegetables, Workshop Proc., September 12-14, 1990. Sheperdstown, WV.

5. Eckert, J. W., and Brown, G. E. 1986. Evaluation of postharvest treatments for citrus fruits. Pages 92-97 in: Methods for Evaluating Pesticides for Control of Plant Pathogens. K. D. Hickey, ed. American Phytopathological Society, St. Paul, MN.

6. Eckert, J. W., and Eaks, I. L. 1989. Postharvest disorders and diseases of citrus fruits. Pages 179-260 in: The Citrus Industry, Vol. 4. W. Reuther, E. C. Calavan, and G. E. Carman, eds. University of California, Berkeley.

7. Eckert, J. W., Sievert, J. R., and Ratnayake, M. 1994. Reduction of imazalil effectiveness against citrus green mold in California packinghouses by resistant biotypes of Penicillium digitatum. Plant Dis. 78:971-974.

8. Fawcett, H. S. 1936. Citrus Diseases and Their Control, 2nd ed. McGraw Hill, New York.

9. Feld, S. J., Menge, J. A., and Pehrson, J. E. 1979. Brown rot of citrus: A review of the disease. Calif. Citrogr. 64:101-106.

10. Harding, P. R., and Savage, D. C. 1964. Investigation of possible correlation of hot-water washing with excessive storage decay in coastal California lemon packing houses. Plant Dis. Rep. 48:808-810.

11. Houck, L. G. 1965. Penicillium development in lemons treated with 2,6-dichloro-4-nitroaniline. Plant Dis. Rep. 49:715-719.

12. Houck, L. G. 1967. Hot water treatments for control of Penicillium green mold of Eureka lemons. (Abstr.) Phytopathology 57:99.

13. Klotz, L. J. 1973. Color Handbook of Citrus Diseases. University of California, Berkeley.

14. Klotz, L. J., and DeWolfe, T. A. 1961. Limitations of the hot water immersion treatment for the control of Phytophthora brown rot of lemons. Plant Dis. Rep. 45:264-267.

15. Klotz, L. J., and DeWolfe, T. A. 1961. Brown rot contact infection of citrus fruits prior to hot water treatment. Plant Dis. Rep. 45:268271.

16. National Research Council. 1993. Pesticides in the Diets of Infants and Children. National Academy Press, Washington, DC.

17. Pelser, P. du T. 1975. Recommendations for the control of post-harvest decay of citrus fruits. S.A. Co-operative Citrus Exchange Ltd., Pretoria, South Africa.

18. Powell, G. H. 1908. The decay of oranges while in transit from California. U.S. Dep. Agric., Bureau Plant Ind., Bull. 123.

19. Schirra, M., and Mulas, M. 1993. Keeping quality of 'Oroblanco' grapefruit-type as affected by hot dip treatments. Adv. Hortic. Sci. 7:73-76.

20. Smilanick, J. L., Margosan, D. A., and Henson, D. J. 1995. Evaluation of heated solutions of sulfur dioxide, ethanol, and hydrogen peroxide to control postharvest green mold of lemons. Plant Dis. 79:742-747.

21. Smoot, J. J., and Melvin, C. F. 1965. Reduction of citrus decay by hot-water treatment. Plant Dis. Rep. 49:463-467.

22. Wild, B. L. 1990. Hot dip treatments reduce chilling injury during storage of citrus fruit at 1 C. Food Res. Quart. 50:36-41.

23. Winston, J. R. 1935. Reducing decay in citrus fruits with borax. U.S. Dep. Agric. Tech. Bull 488. 